\title{
Waste from the biscuit and noodle industries in Nile tilapia diets
}

\section{Resíduos da indústria de biscoitos e massas em dietas para tilápia-do-nilo}

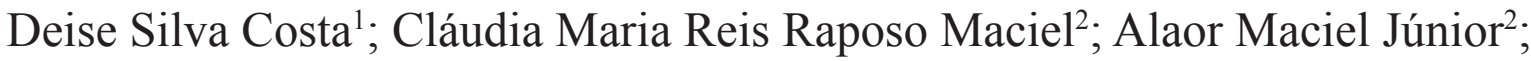 \\ Francisco Oliveira de Magalhães Júnior ${ }^{3}$; Gustavo César Bressan Smith ${ }^{4}$; \\ Marcel José Martins dos Santos ${ }^{3}$; Luís Gustavo Tavares Braga ${ }^{5 *}$
}

\begin{abstract}
The objectives of this work were to determine the apparent digestibility coefficients (ADC) of dry matter (DM), crude protein (CP) and gross energy (GE) of coconut biscuit residues (CBR), sweet biscuits (SBR) and noodles (NR) for Nile tilapia and evaluate the performance of fingerlings fed with diets containing the residues with the highest nutritional value. In the digestibility study, 72 juveniles (with an average weight of $70.5 \pm 2.7 \mathrm{~g}$ ) were organized in a completely randomized design with three treatments and three replications (12 fish per replication). ADC was determined using an indirect method in which $0.10 \%$ chromium oxide $\left(\mathrm{Cr}_{2} \mathrm{O}_{3}\right)$ acted as an indicator. To evaluate performance, 225 fingerlings (with an average weight of $3.4 \pm 0.5 \mathrm{~g}$ ) were distributed across 15 tanks (150 L), creating a completely randomized design with five treatments and three replications. The test diets contained 0,4 , 8,12 or $16 \%$ CBR. ADCDM, ADCCP and ADCGE for each of the different residues were, respectively: 85,88 and $86 \%$ for CBR; 32,51 and $46 \%$ for SBR; 24,31 and $26 \%$ for NR. The inclusion of CBR significantly affected final weight of the fish, specific growth rate and protein retention rate, as well as the carcass composition values for dry matter, mineral matter, gross energy and ethereal extract. CBR presents better digestibility than the other tested residues and it can be used as a substitute for maize meal in quantities up to $11.62 \%$, thus improving fish performance.
\end{abstract}

Key words: Alternative food. Digestibility. Noodle residue. Oreochromis niloticus. Performance.

\section{Resumo}

Objetivou-se determinar os coeficientes de digestibilidade aparente da matéria seca (CDAMS), proteína bruta (CDAPB) e energia bruta (CDAEB) dos resíduos de biscoito de coco (RBC), biscoito doce (RBD) e macarrão (RM) para a tilápia-do-nilo e avaliar o desempenho destes alevinos alimentados com dietas contendo o resíduo com o maior valor nutritivo. No estudo de digestibilidade 72 juvenis $(70,5 \pm 2,7 \mathrm{~g})$ foram distribuídos em um delineamento inteiramente casualizado com três tratamentos e três repetições (12 peixes por repetição). A determinação dos CDA foi realizada pelo método indireto, com a utilização de $0,10 \%$ de óxido crômico $\left(\mathrm{Cr}_{2} \mathrm{O}_{3}\right)$ como indicador. Para avaliação do desempenho 225 alevinos $(3,4 \pm 0,5 \mathrm{~g})$ foram distribuídos em 15 tanques $(150 \mathrm{~L})$, compondo um delineamento inteiramente

\footnotetext{
${ }^{1}$ Discente, Curso de Doutorado, Programa de Pós-Graduação em Desenvolvimento Regional e Meio Ambiente. Universidade Estadual de Santa Cruz, UESC, Ilhéus, BA, Brasil. E-mail: deisezootecnista@gmail.com

2 Profs., Universidade Estadual do Sudoeste da Bahia, UESB, Programa de Pós-Graduação em Ciências Ambientais, Campus Universitário "Juvino Oliveira”, Itapetinga, BA, Brasil. E-mail: claudiaraposomaciel@yahoo.com.br; alaormacjr@yahoo.com.br

3 Discente, Curso de Doutorado, Programa de Pós-Graduação em Ciência Animal, Campus Universitário "Soane Nazaré de Andrade", Ilhéus, BA, Brasil. E-mail:jr.oliveira@zootecnista.com.br; marcel_martins_santos@hotmail.com

${ }^{4}$ Pesquisador. Aquanut, Universidade Estadual de Santa Cruz, UESC, Ilhéus, BA, Brasil. E-mail: gustavobressan1@gmail.com

5 Prof., Programa de Pós-Graduação em Ciência Animal, Campus Universitário "Soane Nazaré de Andrade", Ilhéus, BA, Brasil. E-mail:lgtbraga@gmail.com

* Author for correspondence
} 
casualizado com cinco tratamentos e três repetições. As dietas testes continham níveis de inclusão de 0, 4, 8, 12 e $16 \%$ do RBC. Os CDAMS, CDAPB, CDAEB para os resíduos foram respectivamente: 85,88 e $86 \%$ para RBC; 32, 51 e 46\% para RBD e 24, 31 e 26\%, para RM. A inclusão do RBC afetou significativamente as variáveis: peso final, taxa de crescimento específico e taxa de retenção proteica, assim como os valores da composição da carcaça para matéria seca, matéria mineral, energia bruta e extrato etéreo. O RBC apresenta melhor digestibilidade em relação aos demais resíduos testados, podendo substituir o farelo de milho em até $11,62 \%$, melhorando o desempenho dos peixes.

Palavras-chave: Oreochromis niloticus. Alimento alternativo. Digestibilidade. Desempenho. Resíduo de macarrão.

\section{Introduction}

The food industry generates a large amount of waste along its production chain, which in addition to causing the loss of borders, can result in environmental problems. On the other hand, the use of these residues as raw materials has provided the opportunity to formulate low-cost animal feeds. This may be a feasible alternative that reduces the impacts of environmental pollution and adds value to waste, provided that economic, technical and nutritional issues are considered.

Nile tilapia can be fed on a wide variety of foods, so cultivation systems of this species can utilize diets that contain alternative foods as a substitute for the conventional ingredients commonly used in animal nutrition. The increasing cost of these conventional ingredients causes nutritionists to search for cheaper alternatives, such as residues that have similar, or sometimes even higher, nutritional composition (GALINDO et al., 2009). The success of diets containing these alternatives depends on the knowledge of the nutritional value of the new products, as well as their limitations. In this sense, it is necessary to study the digestibility of the ingredients and the quantity of energy and nutrients they provide, in addition to the nutritional requirements of the species (BOSCOLO et al., 2002; PEZZATO et al., 2002).

Wheat by-products, such as residues from the biscuit and noodle manufacturing processes, have a composition that is similar to that of energy grains (ROSTAGNO et al., 2011), so they have been analyzed as a potential replacement of ingredients such as maize (BOSCOLO et al., 2010; SIGNOR et al., 2007). According to Boggess et al. (2008), these residues have variable compositions that depend on the formula and the ingredients that are used. They are characterized by being non-marketed and damaged products that have undergone excess or insufficient cooking during processing, among other peculiarities, and have not been approved by the quality control in the factory (LIMA; LUDKE, 2011).

In light of this, the objective of this study was to determine the apparent digestibility coefficient of nutrients and gross energy of residues of the food industry (residues of coconut biscuit [CBR], sweet biscuit [SBR] and noodles [NR]) and to evaluate the inclusion of residues with better nutritional value on the performance of Nile tilapia fingerlings.

\section{Materials and Methods}

This study was carried out at the Fish Nutrition and Feeding Laboratory (AQUANUT) of the State University of Santa Cruz (UESC), in Ilhéus, Bahia. In the digestibility test, 72 sexually reversed Nile tilapia (Oreochromis niloticus) juveniles were used, with an average weight of $70.5 \pm 2.7 \mathrm{~g}$. The fish were distributed in a completely randomized design with three treatments and three replications (12 fish per replication) over a period of 30 days. We evaluated the residues of coconut biscuits, sweet biscuits and noodles by quantifying the dry matter $(\mathrm{DM})$, crude protein $(\mathrm{CP})$, ethereal extract $(\mathrm{EE})$, gross energy (GE) and mineral matter (MM) in the Animal Nutrition Laboratory of the State University of Southwest of Bahia (UESB), according to 
Association of Official Analytical Chemists AOAC (2005) methodology (Table 1).

The experiment was composed of digestibility aquariums (200 L) with a conical shape, equipped with a water recirculation system (1.2 L/min), mechanical oxygenation and biological filtration. In the lower part of the aquariums there was a tap equipped with a collector, which was later immersed in ice in a Styrofoam box for stool collection, according to the methodology proposed by Oliveira et al. (2013). The temperature, $\mathrm{pH}$ and dissolved oxygen content of the water were monitored daily with a YSI Professional Plus multiparameter apparatus (YSI Incorporated, Yellow Springs, OH, USA), and over the course of the experiment, the average values were $25.75 \pm 0.8^{\circ} \mathrm{C}, 7.49 \pm 0.3 \mathrm{pH}$ and $8.25 \pm 1.2 \mathrm{mg} / \mathrm{L}$, respectively. These parameters are considered suitable for tropical fish farming (ROSS, 2000).

Table 1. Bromatological composition of food industry waste based on dry matter.

\begin{tabular}{cccccc}
\hline Industry waste & Dry matter (\%) & $\begin{array}{c}\text { Crude protein } \\
(\%)\end{array}$ & $\begin{array}{c}\text { Ethereal extract } \\
(\%)\end{array}$ & $\begin{array}{c}\text { Gross energy } \\
(\mathrm{kcal} / \mathrm{kg})\end{array}$ & $\begin{array}{c}\text { Mineral matter } \\
(\%)\end{array}$ \\
\hline Sweet biscuits & 90.29 & 6.7 & 4.83 & 4,053 & 2.06 \\
Coconut biscuit & 91.73 & 11.2 & 2.78 & 4,020 & 3.63 \\
Noodles & 88.54 & 13.0 & 0.06 & 3,816 & 0.73 \\
\hline
\end{tabular}

We prepared three test diets from the reference diet (Table 2), which contained $70 \%$ of the reference diet and $30 \%$ of the residue, plus $0.1 \%$ of chromium oxide to be used as an inert indicator. The reference diet was composed according to Furuya (2010), using the values of the apparent digestibility coefficient obtained for Nile tilapia (BOSCOLO et al., 2002; PEZZATO et al., 2002).

Table 2. Percentage composition of the reference diet used in the digestibility test for Nile tilapia.

\begin{tabular}{|c|c|}
\hline Ingredient & Amount (\%) \\
\hline Soybean Meal $45 \%^{1}$ & 34.0 \\
\hline Corn meal ${ }^{1}$ & 20.0 \\
\hline Wheat bran ${ }^{1}$ & 15.0 \\
\hline Meat and bones flour $45 \%^{1}$ & 12.60 \\
\hline Fish meal $55 \%^{1}$ & 8.30 \\
\hline Maize starch ${ }^{1}$ & 3.30 \\
\hline Rice meal & 3.08 \\
\hline Soy oil ${ }^{1}$ & 2.50 \\
\hline Mineral and vitamin premix* & 0.50 \\
\hline Regular salt & 0.40 \\
\hline $\mathrm{DL}$ - metionina & 0.20 \\
\hline Antifungal & 0.10 \\
\hline $\mathrm{BHT}^{2}$ & 0.02 \\
\hline Chromium oxide III & 0.10 \\
\hline Total & 100.0 \\
\hline
\end{tabular}

${ }^{1}$ Pratigi Alimentos, Castro Alves, BA, BR.

${ }^{*}$ Composition/ $\mathrm{kg}$ of the product: vit. $\mathrm{A}=6,000,000 \mathrm{IU}$; vit. D3 = 2,250,000 IU; vit. E=75,000mg; vit, K3 = 3,000mg; vit, thiamine $=5,000 \mathrm{mg} ;$ riboflavin $=10,000 \mathrm{mg}$; vit, pyridoxine $=8,000 \mathrm{mg} ;$ Biotin $=2000 \mathrm{mg} ;$ vit, $\mathrm{C}=192,500 \mathrm{mg} ;$ Niacin $=30,000 \mathrm{mg} ;$ Folic acid = 3,000mg; $\mathrm{Fe}=100,000 \mathrm{mg} ; \mathrm{Cu}=600 \mathrm{mg} ; \mathrm{Mn}=60,000 \mathrm{mg} ; \mathrm{Zn}=150,000 \mathrm{mg} ; \mathrm{I}=4,500 \mathrm{mg} ; \mathrm{Cu}=15,000 \mathrm{mg} ; \mathrm{Co}=2,000 \mathrm{mg}$; If $=400 \mathrm{mg}$;

${ }^{2} \mathrm{BHT}=$ Butylated hydroxytoluene. 
The ingredients used in the preparation of the rations were ground in a knife-type mill with a 0.5 $\mathrm{mm}$ matrix and homogenized in an industrial mixer. We then added soybean oil and $25 \%$ warm water $\left(32^{\circ} \mathrm{C}\right)$ to the mixture. The diets were granulated using a reversible pelletizer equipped with a $2 \mathrm{~mm}$ opening matrix. After the formation of the granules, each experimental diet was placed in a stove with forced air circulation at $55^{\circ} \mathrm{C}$ for 24 hours to remove moisture, and was then stored in a refrigerator $\left(4^{\circ} \mathrm{C}\right)$.

The fish underwent a 15-day acclimation period, when they were fed four times a day with commercial feed (with $35 \%$ crude protein and petiole with 2-4 $\mathrm{mm}$ diameter) until apparent satiety. After the adaptation period, the fish were fed their respective experimental diets for three days and a digestibility aquarium was assigned to each of the diets. The replications were obtained over time, such that a pool of excreta from each aquarium was obtained every four days, representing a repetition.

During the fecal collection period the fish were fed with the respective diets five times a day. After the last feeding the aquariums were siphoned and a discharge of water was made to remove possible leftovers from feed and feces. The collectors, wrapped in thermostatic containers and kept at $0^{\circ} \mathrm{C}$, were installed in the mechanisms at the bottom of the aquariums to collect the feces by sedimentation. The following morning, the tilapia feces were collected and transferred to aluminum trays lined with plastic bags, and placed in the forced circulation oven at $55^{\circ} \mathrm{C}$ for 48 hours. After drying, the fecal material was ground in a ball mill and separated from scaling contaminations using tweezers. Finally, the samples were stored in plastic containers, labelled and kept in a refrigerator $\left(4^{\circ} \mathrm{C}\right)$ for further chemical analysis.

The concentration of chromium oxide in the diets and feces was determined by atomic absorption in the Analytical Chemistry Laboratory, and the bromatological composition was determined in the Laboratory of Animal Nutrition of the State University of Santa Cruz, following the methodology of AOAC (2005). The apparent digestibility coefficients of the diets were calculated according to Nose (1966), using the following formula:

$$
\begin{gathered}
\mathrm{ADC}(\%)=100-100 *\left[\left(\% \mathrm{Cr}_{2} \mathrm{O}_{3} \text { in diet } / \%\right.\right. \\
\left.\mathrm{Cr}_{2} \mathrm{O}_{3} \text { in feces }\right) *(\% \text { of nutrient in feces } / \% \text { of } \\
\text { nutrient in diet })]
\end{gathered}
$$

The apparent digestibility coefficients of the tested ingredients were calculated using the following relationship (BUREAU; HUA, 2006):

$$
\begin{gathered}
\mathrm{ADCi}=\left[\left(\mathrm{ADC}_{\mathrm{dt}} * \mathrm{D}_{\mathrm{t}}-\left(\left(\mathrm{ADC}_{\mathrm{dr}} * 0.7 \mathrm{D}_{\mathrm{r}}\right) /\right.\right.\right. \\
\left.\left.\left(0.7 \mathrm{DM}_{\mathrm{dr}}+0.3 \mathrm{DM}_{\mathrm{i}}\right)\right) /\left(0.3 \mathrm{D}_{\mathrm{t}}\right) /\left(0.7 \mathrm{DM}_{\mathrm{dr}}+0.3 \mathrm{DM}_{\mathrm{i}}\right)\right]
\end{gathered}
$$

Where, $\mathrm{ADC}_{\mathrm{dt}}=$ apparent digestibility coefficient of the test diet; $\mathrm{D}_{\mathrm{t}}=\%$ of nutrient (or $\mathrm{kcal} / \mathrm{kg}$ ) of gross energy) of the test diet (dry matter basis); $\mathrm{ADC}_{\mathrm{dr}}=$ apparent digestibility coefficient of the reference diet; $\mathrm{DM}_{\mathrm{dr}}=$ dry matter content of the reference diet; $\mathrm{DM}_{\mathrm{i}}=$ dry matter content of the test ingredient; $\mathrm{D}_{\mathrm{r}}=\%$ of the nutrient (or $\mathrm{kcal} / \mathrm{kg}$ of gross energy) in the reference diet; $\mathrm{D}_{\mathrm{i}}=\%$ of the nutrient (or $\mathrm{kcal} / \mathrm{kg}$ of gross energy) in the test ingredient.

Statistical significance was determined using analysis of variance and the differences between the averages, when applicable, were analyzed using the Tukey test at 5\% probability. Analysis was performed in the statistical software $\mathrm{R}$ ( $\mathrm{R}$ DEVELOPMENT CORE TEAM, 2014).

The trial to evaluate the performance of Nile tilapia fingerlings was 60 days in duration. A total of 225 sexually reversible fish with an initial weight of $3.4 \pm 0.5 \mathrm{~g}$ were distributed in 15 circular tanks $(150 \mathrm{~L})$. We used a completely randomized design with five treatments and three replications, where one tank containing 15 fish was considered to be one experimental unit. The treatments consisted of diets containing an increasing amount of coconut biscuit residues $(20,40,60$ and $80 \%)$ as a 
substitute for corn meal (Table 3), in addition to a control treatment that was free from residues. The diets were formulated according to the nutritional requirements of the species (FURUYA, 2010) and with the apparent digestibility coefficients obtained in the first experiment.

Table 3. Percentage composition of experimental diets with different levels of inclusion of coconut biscuit residue for Nile tilapia fingerlings.

\begin{tabular}{|c|c|c|c|c|c|}
\hline \multirow{2}{*}{ Ingredient $(\%)$} & \multicolumn{5}{|c|}{ Inclusion levels of the coconut biscuit residue (\%) } \\
\hline & 0.00 & 4.00 & 8.00 & 12.00 & 16.00 \\
\hline Soybean meal $45 \%^{1}$ & 37.00 & 36.54 & 37.00 & 37.00 & 36.00 \\
\hline Corn meal ${ }^{1}$ & 20.00 & 16.00 & 12.00 & 8.00 & 4.00 \\
\hline Wheat bran ${ }^{1}$ & 16.60 & 15.70 & 15.62 & 14.70 & 15.00 \\
\hline Corn gluten meal $22 \%^{1}$ & 11.10 & 5.00 & 6.00 & 8.00 & 5.71 \\
\hline Fish meal $55 \%{ }^{1}$ & 9.80 & 12.50 & 12.00 & 11.00 & 12.00 \\
\hline Maize starch ${ }^{1}$ & 3.00 & 7.00 & 6.10 & 6.00 & 8.00 \\
\hline Coconut biscuit & 0.00 & 4.00 & 8.00 & 12.00 & 16.00 \\
\hline Antioxidant $^{2}(\mathrm{BHT})$ & 0.02 & 0.02 & 0.02 & 0.02 & 0.02 \\
\hline Antifungal & 0.10 & 0.10 & 0.10 & 0.1 & 0.1 \\
\hline Mineral and vitamin premix* & 1.38 & 1.38 & 1.38 & 1.38 & 1.38 \\
\hline Regular salt & 0.50 & 0.50 & 0.50 & 0.50 & 0.50 \\
\hline Soy oil ${ }^{1}$ & 0.50 & 1.26 & 1.28 & 1.30 & 1.29 \\
\hline Total & 100.00 & 100.00 & 100.00 & 100.00 & 100.00 \\
\hline \multicolumn{6}{|c|}{ Calculated values } \\
\hline Digestible protein (\%) & 26.1 & 26.1 & 26.4 & 26.2 & 26.0 \\
\hline Digestible energy $(\mathrm{kcal} / \mathrm{kg})$ & 3,084 & 3,122 & 3,133 & 3,140 & 3,140 \\
\hline Crude fiber $(\%)$ & 5.0 & 4.4 & 4.4 & 4.4 & 4.0 \\
\hline Ether extract (\%) & 3.3 & 4.0 & 4.0 & 4.0 & 4.0 \\
\hline Calcium (\%) & 0.71 & 0.86 & 0.83 & 0.78 & 0.83 \\
\hline Phosphor (\%) & 0.79 & 0.84 & 0.82 & 0.79 & 0.81 \\
\hline
\end{tabular}

*Mineral and vitamin premix (Composition / $\mathrm{kg}$ of product): vit. $\mathrm{A}=6,000,000 \mathrm{UI}$; vit, D3 = 2,250,000 UI; vit, $\mathrm{E}=75,000 \mathrm{mg}$; vit, $\mathrm{K} 3=3,000 \mathrm{mg}$; vit, tiamina $=5,000 \mathrm{mg}$; riboflavina $=10,000 \mathrm{mg}$; vit,pirodoxina $=8,000 \mathrm{mg}$; biotina $=2,000 \mathrm{mg} ;$ vit, $\mathrm{C}=192,500 \mathrm{mg}$; niacina $=30,000 \mathrm{mg}$; ácido fólico $=3,000 \mathrm{mg} ; \mathrm{Fe}=100,000 \mathrm{mg} ; \mathrm{Cu}=600 \mathrm{mg} ; \mathrm{Mn}=60,000 \mathrm{mg} ; \mathrm{Zn}=150,000 \mathrm{mg} ; \mathrm{I}=4,500 \mathrm{mg} ; \mathrm{Cu}$ $=15,000 \mathrm{mg} ; \mathrm{Co}=2,000 \mathrm{mg} ; \mathrm{Se}=400 \mathrm{mg}$;

${ }^{2} \mathrm{BHT}=$ Butil-hidroxi-tolueno.

The tanks had a closed water recirculation system and were provided with biological filtration and constant oxygenation from a radial blower. Throughout the experiment the water quality parameters were measured using the YSI Professional Plus digital multiparameter (YSI Incorporated, Yellow Springs, OH, USA). They remained stable and within the comfort range for the species, recording averages of $25.6 \pm 1.1^{\circ} \mathrm{C}$ for temperature, $6.8 \pm 0.1$ for $\mathrm{pH}$ and $3.2 \pm 1.8 \mathrm{mg} / \mathrm{L}$ for dissolved oxygen.
To prepare the diets, the foods were individually processed in a knife-type mill with a $0.5 \mathrm{~mm}$ sieve, weighed on a semi-analytical scale, homogenized in an industrial mixer according to the formulation of each diet and moistened with soybean oil and water before pelleting. After the formation of the granules, the diets were placed in the forced circulation oven at $55^{\circ} \mathrm{C}$ for 24 hours. At the end of the process, the diets were stored in a refrigerator $\left(4^{\circ} \mathrm{C}\right)$ until the beginning of the experiment. The diet consisted of daily rationing divided into four portions (two in the morning and two in the afternoon), and fish were 
fed until apparent satiation. Biometric tests were performed at the beginning and at the end of the experimental period, after the fish were submitted to a 24-hour fasting period for intestinal emptying.

At the start of the experiment, five fish were slaughtered and frozen prior to treatment. This procedure was also performed on two individuals from each replication at the end of the experimental period. The fish were fasted for 24 hours and then sacrificed with an overdose of benzocaine (GOMES et al., 2001) and taken whole for pre-drying in a forced air circulation oven at $55^{\circ} \mathrm{C}$ for 72 hours. Then they were ground in a knife mill, packed in plastic pots and stored in a freezer $\left(-18^{\circ} \mathrm{C}\right)$ for subsequent centesimal analysis. The bromatological analysis of the composition of fish diets and carcasses (dry matter, crude protein, ethereal extract, gross energy and mineral matter) were carried out in the Laboratory of Animal Nutrition and in the Laboratory of Nutrition and Fish Feeding of the State University of Santa Cruz, according to the methodology described by AOAC (2005). Using the data obtained in the biometric tests at the beginning and the end of the experiment, and the analysis of the body composition of the fish, the following variables were determined: diet consumption, weight gain, apparent feed conversion, specific growth rate, protein retention rate and survival (as an evaluation of zootechnical performance).

All data were tested for normality and homogeneity and were subsequently subjected to analysis of variance, and where necessary, a regression analysis was applied to verify the relationship between the variables. Statistical analysis was carried out using the statistical software R (R DEVELOPMENT CORE TEAM, 2014).

\section{Results and Discussion}

The apparent digestibility coefficients of dry matter (ADCDM), crude protein (ADCCP) and gross energy (ADCGE) of the three tested foods (coconut biscuits, sweet biscuits and noodles) included in the diets for Nile tilapia varied (Table 4), indicating that the digestibility of the food presents a close relationship with its chemical composition (PEZZATO et al., 2002). Among the alternative foods used, coconut biscuit residue presented the highest value for the apparent digestibility coefficient of DM, namely above $80 \%$, in comparison to the digestibility of sweet biscuits and noodles, which were below $33 \%$. This difference can be explained by the high rate of soluble non-starch polysaccharides present in the composition of sweet biscuits and noodles, which are not used efficiently by the Nile tilapias. In addition, some of these components act as digestibility reducers, such as pentosans and betaglucans, which cause increased intestinal viscosity, impairing enzymatic action (BEDFORD, 2000). The value we found for the apparent digestibility coefficient of DM of coconut biscuit residue was higher than that observed for triticale $(68.51 \%)$ and wheat bran (66.79\%) (BOSCOLO et al., 2002), and greater than the results found for the residue of sweet biscuits and noodles. Digestibility studies on the use of alternative ingredients for Nile tilapia have been performed at a national and a global level, but it is important that the findings allow for the formulation of rations that better meet the nutritional requirements of the fish, avoiding physiological and environmental overload (PEZZATO et al., 2004). 
Table 4. Average values of apparent digestibility coefficients of dry matter, crude protein and gross energy for Nile tilapia juveniles.

\begin{tabular}{cccc}
\hline \multirow{2}{*}{ Ingredient } & \multicolumn{3}{c}{ Apparent digestibility coefficients (\%) } \\
\cline { 2 - 4 } & Dry matter & Crude protein & Gross energy \\
\hline Coconuts biscuit & $84.75^{\mathrm{a}}$ & $88.38^{\mathrm{a}}$ & $86.44^{\mathrm{a}}$ \\
Sweet biscuit & $32.22^{\mathrm{b}}$ & $51.34^{\mathrm{b}}$ & $45.94^{\mathrm{b}}$ \\
Noodles & $23.58^{\mathrm{b}}$ & $30.88^{\mathrm{c}}$ & $25.85^{\mathrm{c}}$ \\
Coefficient of variation (\%) & 12.91 & 8.28 & 9.99 \\
P-value & 0.001 & 0.001 & 0.001 \\
\hline
\end{tabular}

Averages in the same row followed by different letters show significant differences for the Tukey test $(\mathrm{p}<0.05)$.

For CP, the highest apparent digestibility coefficient was obtained for coconut biscuit residue. It is important to emphasize that there are few studies in the academic literature about the digestibility of this residue; however, when compared to other ingredients, it is superior to the residues of vitiviniculture $(67.25 \%$; ARAÚJO, 2012) and cassava flour (77.64\%; SANTOS et al., 2009a) in studies on the Nile tilapia. Similar values were observed by Campeche et al. (2011) in digestibility tests using foods found in the Brazilian semi-arid region; namely cassava scraps $(88.19 \%)$ and sorghum (88.56\%). The ADCCP of the residues of sweet biscuits and noodles were lower than for the residues of guava meal $(61.49 \%$; SANTOS et al., 2009a) and broken cassava meal (72.04\%; SANTOS et al., 2009b). Similar values to those obtained in this study were found by Braga et al. (2010), who reported digestibility coefficients of $51.61 \%$ for algarroba meal and $38.47 \%$ for cocoa meal. According to Santos et al. (2005) and Nunes et al. (2001), the differences between the ingredients of industrial waste are due to the composition of the raw materials and the manufacturing process used during its production, which may influence the nutritional value of the food. Another relevant factor may be associated with the preparation of the feed. The pelletization of feed may cause changes in its physical and chemical characteristics, especially in regard to pellet resistance and stability and nutrient digestibility (BOOTH et al., 2000).
The apparent digestibility coefficient of GE was highest in coconut biscuit residues. According to Boggess et al. (2008), biscuit residue is an alternative food source that has high levels of sugars and fats. It has an energy value above $4,400 \mathrm{kcal} / \mathrm{kg}$, which is higher than the gross energy contained in maize $(3,925 \mathrm{kcal} / \mathrm{kg}$ ) (ROSTAGNO et al., 2011). The result found here for coconut biscuits was similar to that of whole wheat $(87.07 \%)$ and higher than that of wheat bran (68.81\%) (BOSCOLO et al., 2002). Teixeira et al. (2010) found values for rice grits $(46.92 \%)$ and sorghum $(47.76 \%)$ that were similar to the ADCGE obtained for sweet biscuits. However, Lima et al. (2011) found a higher value of ADCGE for mango residue (36.68\%) than the result obtained for noodle residue in this study.

The performance of Nile tilapia juveniles fed on diets containing different levels of coconut biscuit residue was studied, and no significant differences $(\mathrm{P}$ $>0.05$ ) were observed for the parameters weight gain, feed intake, apparent feed conversion and survival rate. However, statistical differences were observed for specific growth rate, as well as for the protein retention rate among fish fed with diets containing $0,4,8,12$ and $16 \%$ of coconut biscuit residue. There was a linear increase in specific growth rate $(\mathrm{P}=0.0581)$ as the level of dietary residue increased and a quadratic effect on protein retention rate $(\mathrm{P}=$ 0.0569) was observed, indicating that the inclusion of coconut biscuit residue influenced the efficiency of absorption of the protein in the feed into the body (Table 5). Similar results were observed in the use 
of starch-rich energy foods, whereby there were no changes in Nile tilapia performance when they received increasing levels of wheat $(0-100 \%)$ and cassava (0-24\%); (SIGNOR et al., 2007). These results indicate that the Nile tilapia efficiently absorbs starchy foods.

Table 5. Performance of Nile tilapia fingerlings fed with diets containing different levels of coconut biscuit residue.

\begin{tabular}{cccccccc}
\hline Variable & \multicolumn{7}{c}{ Inclusion levels of the coconut biscuit residue (\%) } \\
\cline { 2 - 6 } Weight gain $(\mathrm{g})$ & 0.00 & 4.00 & 8.00 & 12.00 & 16.00 & CV\% & P value \\
Feed intake $(\mathrm{g})$ & 36.60 & 37.05 & 40.06 & 44.91 & 38.25 & 7.05 & 0.1489 \\
Rate feed conversion (\%) & 44.07 & 42.82 & 40.79 & 46.12 & 43.21 & 8.80 & NS \\
\hline Survival (\%) & 1.21 & 1.07 & 1.10 & 1.03 & 1.13 & 7.81 & 0.0751 \\
\hline Specific growth rate (\%)* & 95.56 & 95.56 & 97.78 & 93.33 & 97.78 & 7.17 & NS \\
Protein retention rate (\%)** & 39.66 & 0.67 & 0.62 & 0.75 & 0.69 & 8.95 & 0.0581 \\
\end{tabular}

*Linear effect: Specific growth rate $\left(\mathrm{Y}=0.006 \mathrm{x}+0.62 ; \mathrm{R}^{2}=0.45\right)$;

$* *$ Quadratic effect: Protein retention rate $\left(\mathrm{Y}=-0.093 \mathrm{x}^{2}+2.177 \mathrm{x}+39.71 ; \mathrm{R}^{2}=0.95\right)$;

$\mathrm{NS}=$ Not significant.

Fish carcasses varied in centesimal composition in relation to the concentration of biscuit residue that they received (Table 6); there were significant differences in gross energy $(\mathrm{P}=0.0080)$, ethereal extract $(\mathrm{P}=0.0019)$ and dry matter $(\mathrm{P}=0.0139)$. The affected variables showed a quadratic effect, indicating an expressive increase as the residue was added. Shearer (1994) stated that centesimal composition can undergo endogenous and exogenous variations according to the genetics of the fish, the food they receive and the characteristics of their environment. These results differ from those obtained by Lui et al. (2012), who analyzed different levels of inclusion of organic wheat in diets and did not observe changes in the chemical composition of the fish. However, the results corroborate with Souza et al. (2013), who evaluated the impact of mango flour on the growth and body composition of Nile tilapia and observed a significantly lower percentage of ethereal extract in animals that received a diet of $100 \%$ mango flour. In the present study, no significant differences were found among carcasses in their mineral matter or crude protein content. This finding may indicate that the test diets presented similar protein levels, since the body's chemical composition is closely linked to the diet composition (VEIVERBERG et al., 2010).

There is little description of carbohydrate types and centesimal composition of fish carcasses in the academic literature; most of the information is related to protein, energy and lipids in the diets. Animals fed with isoprotein and isoenergetic diets, without variation in lipid content, normally do not present differences in their basic chemical composition. However, the results presented in this study show that the carbohydrate concentrations tested in the diet modified the chemical profile of the carcass of the animals. 
Table 6. Bromatological composition of the carcasses of Nile tilapia fingerlings fed with diets containing different levels of coconut biscuit residue based on dry matter.

\begin{tabular}{cccccccc}
\hline Variable & \multicolumn{9}{c}{ Inclusion levels } & \multirow{2}{*}{ P value } \\
\cline { 2 - 6 } & 0.00 & 4.00 & 8.00 & 12.00 & 16.00 & CV & \\
\hline Gross energy* & 4,870 & 5,301 & 5,242 & 5,231 & 5,104 & 3.08 & 0.0080 \\
Ethereal extract* & 9.59 & 12.06 & 12.14 & 12.35 & 10.87 & 7.60 & 0.0019 \\
Crude protein & 12.97 & 12.85 & 13.57 & 13.04 & 11.25 & 7.27 & 0.4934 \\
Dry matter* & 22.11 & 24.54 & 24.90 & 25.82 & 23.73 & 5.44 & 0.0137 \\
Mineral matter & 13.73 & 12.68 & 12.96 & 13.14 & 13.32 & 7.87 & 0.3173 \\
\hline
\end{tabular}

*Quadratic effect: Raw energy $\left(\mathrm{Y}=-5.06 \mathrm{x}^{2}+92.66 \mathrm{x}+4917.21 ; \mathrm{R}^{2}=0.82\right)$; Ethereal extract $\left(\mathrm{Y}=-0.03465 \mathrm{x}^{2}+0.6259 \mathrm{x}+9.7202\right.$; $\left.\mathrm{R}^{2}=0.94\right)$; Dry matter $\left(\mathrm{Y}=-0.03788 \mathrm{x}^{2}+0.7192 \mathrm{x}+22.105 ; \mathrm{R}^{2}=0.92\right)$.

\section{Conclusions}

Coconut biscuit residue presents the best nutrient digestibility coefficient of the three residues tested here and it proves to be a promising alternative food; it can be included at levels up to $11.62 \%$ in diets for Nile tilapia fingerlings, improving their zootechnical performance.

\section{Acknowledgements}

Special thanks to the Coordination for the Improvement of Higher Education Personnel (CAPES) for granting the master's degree; to Petyan Indústria de Alimentos Ltda, for the donation of waste; to Aguavale Piscicultura, for the donation of fish; to Professor Raildo Mota de Jesus, through the Laboratory of Analytical Chemistry of the State University of Santa Cruz, for the performance of chromium oxide analysis.

\section{References}

ARAÚJO, J. R.; SANTOS, L. D.; SILVA OTANAEL, L. C. R.; MEURER, O. D. S. F. Digestibilidade aparente de ingredientes do Semi-Árido Nordestino para tilápia do Nilo. Ciência Rural, Santa Maria, v. 42, n. 5, p. 900-903, 2012.

ASSOCIATION OF OFFICIAL ANALYTICAL CHEMISTS - AOAC. Official methods of analysis. $16^{\text {th }}$ ed. Washington D.C., 2005.
BEDFORD, M. R. Exogenous enzymes in monogastric nutrition: their current value and future benefits. Animal Feed Science and Technology, Amsterdam, v. 86, n. 1, p. $1-13,2000$.

BOGGESS, M.; STEIN, H. H.; DEROUCHEY, J. Alternative feed ingredients in swine diets. Illinois, 2008. Disponível em: <http://nutrition.ansci.illinois.edu/sites/ default/files/AlternativeFeedIngredientsSwine Diets. pdf>. Acesso em: set. 2016.

BOOTH, M. A.; ALLAN, G. L.; WARNER-SMITH, R. Effects of grinding, steam conditioning and extrusion of a pratical diet on digestibility and weight gain of silver perch, Bidyanus bidyanus. Aquaculture, Amsterdam, v. 182, n. 3-4, p. 287-299, 2000.

BOSCOLO, W. R.; HAYASHI, C.; MEURER, F. Digestibilidade aparente da energia e nutrientes de alimentos convencionais e alternativos para a tilápia do Nilo (Oreochromis niloticus, L.). Revista Brasileira de Zootecnia, Viçosa, v. 31, n. 2, p. 539-545, 2002.

BOSCOLO, W. R.; HAYASHI, C.; MEURER, F. Inclusão de milheto em dietas para alevinos de tilápia-do-nilo formuladas com base na proteína e energia digestíveis. Revista Brasileira de Zootecnia, Viçosa, v. 39, n. 5, p. 950-954, 2010.

BRAGA, L. G. T.; RODRIGUES, F. L.; AZEVEDO, R. V.; CARVALHO, J. S. O.; RAMOS, A. P. S. Digestibilidade aparente da energia e nutrientes de coprodutos agroindustriais para tilápia do Nilo. Revista Brasileira de Saúde e Produção Animal, Salvador, v. 11, n. 4, p. 1127-1136, 2010.

BUREAU, D. P.; HUA, K. Letter to the editor of aquaculture. Aquaculture, Amsterdam, v. 252, n. 2, p. 103-105, 2006. 
CAMPECHE, D. F. B.; MORAES, S. A.; LIMA, V. T.; SOUSA, S. M. N.; OLIVEIRA, S. T. L.; SOUZA, M. G.; PAULINO, R. V. Composição bromatológica e digestibilidade aparente de alimentos encontrados na região semiárida brasileira para arraçoamento de tilapia rosa em cultivos. Ciência Rural, Santa Maria, v. 41, n. 2, p. 343-348, 2011.

FURUYA, W. M.; PEZZATO, L. E.; BARROS, M. M.; BOSCOLO, W. R.; CYRINO, J. E. P.; FURUYA, V. R. B.; FEIDEN, A. Tabelas brasileiras para a nutrição de tilápias. Toledo: Gráfica \& Editora, 2010. p. 45-48.

GALINDO, E. L. O; LUDKE, M. C. M. M.; BARBOSA, J. M.; LUDKE, J. V.; LIMA, M. R.; SANTOS, E. L.; WINTERLE, W. M. C.; MENDONCA, I. T. L.; CARRARO, F. G. P. Composição bromatológica e digestibilidade do resíduo de tomate como alimento energético para produção de tilápia do Nilo (Oreochromis niloticus). Revista Brasileira de Nutrição Animal, Fortaleza, v. 3, n. 5, p. 34-50, 2009.

GOMES, L. C.; CHIPPARI-GOMES, A. R.; LOPES, N. P.; ROUBACH, R.; ARAUJO-LIMA, C. A. R. M. Efficacy of benzocaine as an anesthetic in juvenile tambaqui Colossoma macropomum. Journal of the World Aquaculture Society, Baton Rouge, v. 32, n. 4, p. 426431, 2001.

LIMA, M. R.; LUDKE, M. C. M. M. Utilização de ingredientes energéticos pela tilápia do Nilo. Revista Eletrônica Nutritime, São Paulo, v. 8, n. 2, p. 1418-1430, 2011.

LIMA, M. R.; LUDKE, M. C. M. M.; PORTO NETO, F. F.; PINTO, B. W. C.; TORRES, T. R.; SOUZA, E. J. O. Farelo de resíduo de manga para tilápia do Nilo. Acta Scientiarum. Animal Sciences, Maringá, v. 33, n. 1, p. 65$71,2011$.

LUI, T. A.; NEU, D. H.; BOSCOLO, W. R.; BITTENCOURT, F.; FREITAS, J. M. A.; FEIDEN, A. Uso de trigo orgânico na alimentação de juvenis de tilápia do Nilo. Pesquisa Agropecuária Tropical, Goiânia, v. 42, n. 4, p. 383-389, 2012.

NOSE, T. Recents advances in the study of fish digestion in Japan. In: SYMPOSIUM ON FEEDING TROUT AND SALMON CULTURE, SC II7, 1966, Belgrade. Proceedings... Belgrade: EIFAC, 1966. p. 17.

NUNES, R. V.; ROSTAGNO, H. S.; ALBINO, L. F. T.; GOMES, P. C.; TOLEDO, R. S. Composição bromatológica, energia metabolizável e equações de predição de energia do grão e subprodutos do trigo para pinto de corte. Revista Brasileira de Zootecnia, Viçosa, v. 30, n. 3, p. 785-793, 2001.
OLIVEIRA, M. S.; LIMA, K. S.; CIPRIANO, F. S.; TONINI, W. C. T.; AZEVEDO, R. V.; SALARO, A. L.; BRAGA, L. G. T. Digestibility of nutrients and energy of cultivars of forage palm for growing Nile tilapia. Semina: Ciências Agrárias, Londrina, v. 34, n. 3, p. 1411-1420, 2013.

PEZZATO, L. E.; MIRANDA, E. C.; BARROS, M. M.; FURUYA, W. M.; PINTO, L. G. Q. Digestibilidade aparente da matéria seca e da proteína bruta e a energia digestível de alguns alimentos alternativos pela tilápia do Nilo (Oreochromis niloticus). Acta Scientiarum. Animal Sciences, Maringá, v. 26, n. 3, p. 329-337, 2004.

PEZZATO, L. E.; MIRANDA, E. D.; BARROS, M. M.; PINTO, L. G. Q.; FURUYA, W. M.; PEZZATO, A. C. Digestibilidade aparente de ingredientes pela tilápia do Nilo (Oreochromis niloticus). Revista Brasileira de Zootecnia, Viçosa, v. 31, n. 4, p. 1595-1604, 2002.

R DEVELOPMENT CORE TEAM. $R$ : a language and environment for statistical computing. R Foundation for Statistical Computing, Vienna, 2008. Disponível em: $<$ http://www.R-project.org>. Acesso em: 14 fev. 2014.

ROSS, L. G. Environmental physiology and energetics. In: BEVERIDGE, M. C. M.; McANDREW, B. J. (Ed.). Tilapias: biology and exploitation. Dordrecht: Kluwer Academic Publishers, 2000. p. 89-128.

ROSTAGNO, H. S.; ALBINO, L. F. T.; DONZELE, J. L.; GOMES, P. C.; OLIVEIRA, R. F.; LOPES, D. C.; FERREIRA, A. S.; BARRETO, S. L. T.; EUCLIDES, R. F. Tabelas brasileiras para aves e suínos: composição de alimentos e exigências nutricionais. 3. ed. Viçosa, MG: Editora UFV, 2011. 252 p.

SANTOS, E. L.; LUDKE, M. C. M. M.; RAMOS, A. M. P.; LUDKE, J. V.; RABELLO, C. B. V. Digestibilidade de subprodutos da mandioca para tilápia do Nilo. Revista Brasileira de Ciências Agrárias, Recife, v. 4, n. 3, p. 358362, $2009 \mathrm{~b}$.

SANTOS, E. L.; LUDKE, M. D. C. M.; BARBOSA, J. M.; RABELLO, C. B. V.; LUDKE, J. V. Digestibilidade aparente do farelo de coco e resíduo de goiaba pela tilápia do Nilo (Oreochromis niloticus). Revista Caatinga, Mossoró, v. 22, n. 2, p. 175-180, 2009a.

SANTOS, Z. A. S.; FREITAS, R. T. F.; FIALHO, E. T.; RODRIGUES, P. B.; LIMA, J. A.; CARELlOS, D. C.; BRANCO,P.A.C.; CANTARELLI, V.S. Valor nutricional de alimentos para suínos determinado na Universidade Federal de Lavras. Ciência e Agrotecnologia, Lavras, v. 29, n. 1, p. 232-237, 2005. 
SHEARER, K. D. Factors affecting the proximate composition of cultured fishes with emphasis on salmonids. Aquaculture, Amsterdam, v. 119, n. 1, p. 6388, 1994.

SIGNOR, A. A.; BOSCOLO, W. R.; FEIDEN, A.; SIGNOR, A.; REIDEL, A. Wheat midlings in the nile tilapia feeding (Oreochromis niloticus L.): digestibility and performance. Ciência Rural, Santa Maria, v. 37, n. 4, p. 1116-1121, 2007.

SOUZA, R. C.; MELO, J. F. B.; NOGUEIRA FILHO, R. M.; CAMPECHE, D. F. B.; FIGUEIREDO, R. A. C. R. Influência da farinha de manga no crescimento e composição corporal da tilápia do Nilo. Archivos de Zootecnia, Viçosa, v. 62, n. 238, p. 217-225, 2013.
TEIXEIRA, E. de A.; SALIBA, E. de O. S.; EULER, A. C. C.; FARIA, P. M. C. de; CREPALDI, D. V.; RIBEIRO, L. P. Coeficientes de digestibilidade aparente de alimentos energéticos para juvenis de surubim. Revista Brasileira de Zootecnia, Viçosa, v. 39, n. 6, 2010.

VEIVERBERG, C. A.; RADÜNZ NETO, J.; SILVA, L. P.; SUTILI, F. J.; ROSSATO, S.; CORRÊIA, V. Teores de proteína bruta em dietas práticas para juvenis de carpa capim. Arquivo Brasileiro de Medicina Veterinária e Zootecnia, Belo Horizonte, v. 62, n. 5, p. 1241-1249, 2010. 
